\title{
Governance and Growth: History, Ideology and Methods of Proof
}

\author{
Mushtaq H. Khan \\ SOAS, University of London
}

\begin{abstract}
There is a broad consensus that sustaining growth in poor countries is a challenge not only because the right economic policies have to be identified but also because policies have to be supported by appropriate governance capabilities, which in poor countries are correspondingly weak. Weaknesses in governance have therefore received a great deal of attention in Africa and other poorly performing areas of the world. However, there is much less agreement about the specific governance capabilities that are required to trigger and sustain growth in countries at different levels of development and facing different development problems. This chapter points out ideological, methodological and historical differences in the ways that governance is understood by making a distinction between the dominant liberal approach to governance, which we call 'market-enhancing' governance (and which is generally referred to as good governance), and an alternative view of governance appropriate for developing countries which draws on the historical evidence of catching up. We describe the alternative approach as 'growth-enhancing' governance.
\end{abstract}

The divide between these approaches is not just about the underlying economic theory and reading of history. Their differences touch on broader differences within economics and the social sciences about how relevant knowledge about social change and policy can be acquired and tested with data and historical knowledge. As such, the debate about governance also flags deeper differences within the social sciences that policy-makers need to be aware of. Methods of research and testing of hypotheses are not 'right' or 'wrong' because it is very difficult to disprove the validity or otherwise of broad analytical methods. Instead, we can at least make policy-makers aware of the differences between methods, the strengths and weaknesses of each, and allow them to assess the plausibility of competing explanations and their applicability and appropriateness for their particular context.

Governance refers to how state and society interact. Therefore questions about governance cannot be separated from broader questions about the economic role of the state in sustaining growth. Many of the dominant views on governance reform priorities for developing countries implicitly draw on a particular view of the role of the state that is based on a view of markets as largely able on their own to allocate resources and draw forth entrepreneurial capabilities that are necessary for sustaining economic development. This view argues that the appropriate governance capabilities to ensure growth and development should be market-supporting governance capabilities to maintain a rule of law, stable property rights, control corruption and operate political institutions that ensure accountability through democratic processes.

This view, which we describe as the liberal 'good governance' or 'market-enhancing' approach draws heavily on contemporary advanced capitalist countries as models for the types of governance capabilities developing countries should be trying to achieve. Apart from the weakness of the underlying theoretical models, the empirical support 
for this view comes from a particular reading of the empirical and historical evidence that is partial and in many respects seriously misleading. The long run correlation between the emergence of liberal market-enhancing institutions and prosperity is not in question. What is in question is the importance of these institutions as sufficient or even necessary conditions for supporting growth and development in poor countries at early stages of development. Here, the historical evidence on processes of change does not provide strong support for the good governance or market-enhancing view of governance priorities. This alone has important implications for the plausibility of the reform agenda that flows from it.

The good governance or market-enhancing governance approach is part of a much broader tradition within modern liberal economics which develops economic models from a minimal set of 'plausible' first principles and then looks to cross-country or historical evidence using regression analysis on relatively large data sets to see if particular hypotheses are rejected or supported. This approach to evidence and proof does not work too well in any branch of economics because if data have to be available for every country we are limited to working with variables that have to be 'coarsely' defined to give a value in every country. This is particularly problematic if an assessment of long historical processes is involved. If we have a prior presumption that history worked in a particular way, and if we keep looking at this type of coarse data, we will eventually find some way of working on the data or some bits of history that appear to fit. If enough economists start working with these models and the available data in the same way, soon the hypotheses take on the appearance of truth.

Alternative approaches to social understanding start from historical readings of processes of change and transformation in different countries and then attempt to build plausible theoretical models of historical change. An immediate advantage of the alternative approach is that while processes of social change may be broadly similar across countries, very different combinations and even types of variables may have provided solutions to similar problems in different countries. But this requires a demanding combination of historical, political, social and economic knowledge. It also draws more heavily on case studies and comparisons of groups of countries using case studies. The plausibility of these theories is based on the plausibility of the historical analysis and comparisons of increasingly large numbers of case studies, but the nature of the data in these theories often precludes tests using cross-country regression analysis. It is important to point out that there is no consensus within economics or other social sciences about the relative merits of different methodologies. Nevertheless, it is important for us to be aware that the use of any particular methodological approach has advantages and disadvantages, particularly if each is likely to give different answers. In the end, it is up to each of us to decide which approach is more plausible and more likely to provide workable policies and approaches for the broader reform process in each country.

Thus, these alternative approaches to governance not only take a different position on theoretical aspects of how markets and states work, but often derive this analysis from different methods of reading the processes of economic transformation in developing countries. For instance, a historical method of looking at the emergence of marketenhancing governance capabilities in contemporary advanced countries soon shows that no country achieved significant 'good governance' capabilities before they developed. Once persistent historical processes are identified we can begin to look for 
general theoretical reasons to explain why these patterns exist. It turns out that good governance capabilities are actually capabilities of delivering significantly expensive public goods and it is difficult if not impossible to achieve this to any significant degree in very poor economies with limited fiscal resources. Since some countries nevertheless developed, we have to conclude that good governance as it has been defined cannot plausibly be a precondition for development. Thus, the problem of looking at the cross-country data in an ahistorical way is that the dominant governance models miss more important questions about the processes through which market-enhancing governance itself developed. How did successful countries achieve better governance as described by good governance characteristics? Did they conjure up good governance before they developed and develop as a result? Or did they have other governance capabilities that allowed them to grow and then sequentially develop aspects of good governance as the growth process generated resources to pay for the public goods that good governance represents?

The case study evidence from the successful developers of the last century which we have reviewed elsewhere shows that the growth process is much better described by the second type of process (Khan 2000b, 2002, 2004a, 2005, 2006). Successful countries had critical 'growth-promoting' governance capabilities that allowed them to sustain growth but these were very different from the capabilities identified by the dominant liberal good governance consensus. As they grew, characteristics described by the good governance model did indeed emerge, and did indeed assist their economic performance in some ways as they emerged. As a result, if we look at the cross-country data we can indeed find 'proof' that good governance is associated both with higher incomes and to a weaker extent even with growth. But these correlations do not tell us how the successful countries actually achieved and sustained growth. They miss out the critical process questions that would help us identify vital growthenhancing governance capabilities. But these are the only questions of much interest for developing economies who want to know what they should be doing.

Instead of the broad public goods describing good governance we find that successful countries instead had a more limited and specific set of capabilities and political arrangements that allowed their states to push accumulation, technology acquisition, resource allocation and political stabilization in very difficult contexts using an array of pragmatic strategies that differed from country to country. Some of these developers were dramatically successful, others less so. Their governance capabilities and political arrangements also display considerable variation across countries. This variation and the absence of a blue print has been a disadvantage for the historical approach because policy advisors from advanced countries have tried to protect developing countries from the possibility of making mistakes that comes from the absence of hard guidelines. But the attempt to protect developing societies from the dangers of policy autonomy is not only deeply patronizing it can be deeply damaging as well. Even if some states have made serious and costly mistakes in the past and even if there were such things as 'right policies' known to more intelligent policymakers from other countries, societies cannot be put on sustainable growth paths by introducing the 'right' policies and limiting the autonomy of their states to make variations.

Growth requires a continuous adaptation to changing economic and political circumstances and this most vital capability can be destroyed or prevented from 
developing by the assumption that policy autonomy is dangerous and developing countries need to be protected from too much autonomy for their policy-makers. Even the most ideological supporters of market economics will concede that within broad limits sustaining growth requires a significant amount of policy autonomy to respond to crisis and challenge in creative ways. Indeed, crisis and challenge can be created by the operation of markets themselves, a fact that we are temporarily reminded of during deep global crises and then tend to forget very rapidly. More seriously, the historical reality is that the ability to act autonomously may be even more important at earlier stages of development because there is actually a much wider range of variation in successful strategies of social transformation than would be conceded by market-fundamentalist economists.

Sustaining growth and development requires nothing less than the transformation of pre-capitalist and largely agrarian societies into modern productive ones. These processes involve interlinked strategies of accumulation, technology acquisition, and the management of deeply conflictual processes of social and class transformation. Given that societies start with different political, social and economic histories, it is hardly surprising that there is no blueprint of transformation that we can discern in actual history. The real irony is that in sanitizing the messiness of history, the sequence of reforms identified in the good governance strategy identifies a series of reform steps that were never actually successfully followed as reform priorities by any real country making the transition from poverty to development. The danger is that by setting the apparently plausible set of good governance capabilities as the priority policy goal for developing countries, policy-makers may have set them a task that they cannot possibly achieve.

The 'growth-enhancing' approach to governance not only draws on a richer historical experience, it is also supported by a wide range of economic theory that shows that the state plays a fundamental transformational role in the transition to development (Stiglitz 1987, 1989b, 1989a; Khan 2004a, 2007a; Stiglitz 2007). This is partly because 'market failures' are endemic in all economies, particularly in developing ones. The liberal economics approach assumes that most market failures are caused by bad states intervening in silly ways (and indeed examples of such interventions are easily found). Therefore the solution to market failures in the dominant view is to get the state out of the economy, and to focus on governance capabilities that allow markets to work better. But in reality there are many significant market failures that would still remain, particularly in developing countries where a reasonably effective market is difficult to construct for structural reasons to do with the cost of providing the vital governance-related public goods. In these contexts, successful development requires the identification of significant market failures (which may be different in different countries) and finding solutions to them that limit the risk of government failure. As the political and social conditions of countries determine the types of likely government failures, successful solutions are likely to vary across countries. The growth-enhancing governance agenda is about identifying significant market failures country by country, and developing the capabilities to respond to them in ways that limit the risk of government failures. Far from reducing the autonomy of states, this approach seeks to create strong capabilities (as much as is possible in each country) to discover and find solutions appropriate to their conditions. 
The absence of blueprints is therefore a feature of the historical problem, not a weakness of the historical methodology. As the internal political histories and class structures of countries are different, as well as their economic problems, it is not surprising that there are no blueprints for successful growth-promoting governance. Nevertheless, even if blueprints are not available, the growth-enhancing governance analysis can give political leaders, state officials, emerging entrepreneurs and representatives of other classes and groups in developing countries alternative sets of questions about the goals of governance in societies going through developmental transformations. Ultimately, societies have to devise their own political compromise and governance institutions that can pragmatically address their growth challenges as best as possible given their specific historical and political constraints. The policy priority for poor countries is not to measure themselves against good governance scores and attempt to improve these scores but to identify areas of governance that are most likely to make a difference to the growth challenges they face.

\section{Governance and Institutions}

Economic development requires an appropriate framework of institutional rules to accelerate and sustain growth and achieve other social objectives. A framework of rules creates the incentives and opportunities that promote growth and social objectives as well as creating sanctions for behaviour that is counterproductive. This much is widely recognized by policy-makers in both developing and advanced countries. The question for poor developing countries is a more specific one. These countries uniformly suffer from weak governance capabilities, so in principle improvements along a wide variety of fronts could be called for. The specific problem is therefore to identify the most important rules and developing the appropriate governance capabilities for enforcing these rules.

A distinction immediately emerges between institutional rules that may be optimal in terms of economic theory or in terms of observations of how more advanced and successful countries operate and rules that can actually be enforced given the historical and political conditions of particular countries. When Douglass North (1990) defined institutions as rules, he was careful to point out that the existence of a formal rule meant little if it could not be enforced. The significance of this observation is often missed. Most developing countries have many rules that are very good rules on paper. In practice the reality is often very different. The discussion about governance priorities is therefore both about the particular rules that a developing country needs to enforce to accelerate growth and development, and also about the governance capabilities that need to be developed to enforce particular rules. If very ambitious public goods like a comprehensive rule of law cannot be effectively enforced then focusing on the enforcement of specific rules that are vital for economic performance, social justice or political stability may be crucial.

The choice of rules and enforcement capabilities are closely related because if a particular set of rules cannot be enforced, focusing on those rules and governance capabilities may not be appropriate. The desirability of many rules that would work to make markets more efficient or contracts easier to enforce is often not in question. We may even find strong empirical support 'proving' the importance of some of these institutions when we compare less developed with more developed countries. We may find that the rules under discussion not only exist in more advanced countries, they do also work to make markets more efficient in the way theory suggests. But if it is 
implausible to enforce some of these rules in any effective way in a particular country, or to make sufficient improvements in governance capabilities that would improve the enforcement of these rules over a reasonable time frame, these rules may be inappropriate as policy priorities in a practical sense.

This may be obvious but is frequently ignored in policy discussions. Developing countries have often been criticized for attempting excessively ambitious interventionist programmes in the past. Often the very same countries are now regularly urged to embark on massively ambitious programmes of improving the rule of law, reducing corruption across the board, improving the accountability of government and other equally ambitious 'good governance' measures. These may all be desirable in their own right but they are unlikely to be achieved in the medium term to an extent that is likely to make a significant impact on the economic performance of the country. This does not mean that these reforms should not be pursued. Precisely because most of these reforms are desirable in their own right, they should indeed be pursued. But they cannot be the core of a growth-promoting strategy with immediate and intermediate objectives. Accelerating growth even in the medium term does require appropriate policies and institutions and these in turn require specific governance requirements if they are to be successfully implemented.

From this practical perspective, the design of a growth promoting governance strategy must begin with a discussion of an economic growth strategy and its compatibility with the political economy of the country which determines its likelihood of implementation and enforcement. This suggests that the identification of the governance priorities for growth is likely to be an iterative process where the most promising growth strategies and complementary governance capabilities are simultaneously identified. Other things being equal, a growth strategy that is most likely to promote growth is one where the growth strategy has governance requirements that are likely to be delivered. As a practical question, we need to identify the critical governance requirements for particular growth strategies and make the achievement of these governance capabilities the priorities for governance reform.

\section{Governance and Growth}

The ability to compete in global markets has rightly been identified as an essential condition for sustaining growth. However, it is often wrongly concluded that since competitiveness is critical, it is sufficient to introduce free markets and expose domestic producers to the competitive discipline of global markets. If free markets mean the adoption of policies that prevent domestic producers getting assistance to achieve competitiveness in global markets, free markets may have very different effects on growth depending on the already pre-existing productive capabilities of the country. If domestic producers are far away from the global frontier of productivity, product quality and price, free markets could lead to a collapse of domestic productive capacity rather than a rapid improvement in productivity. The possibility that free markets could lead to divergence rather than convergence was most powerfully experienced by many developing countries during their colonial history when virtual free trade was accompanied in most cases by a growing divergence between themselves and the advanced countries. 
For instance, from 1873 to 1947 Indian per capita income declined from around 25\% of US per capita income to under $10 \%$ of the US level (Clark and Wolcott 2002). This happened during a period of virtual free trade as India was only allowed minimal tariff protection, a period when there was relatively strong protection of the rights of foreign (British) investors and virtually no restrictions on the repatriation of capital and profit. The proximate cause of this relative decline was simply that it was not profitable to invest in higher productivity manufacturing industries in India because of the low productivity of Indian workers, which was so low that even its low wages compared to the home country did not give India a competitive advantage for prospective British investors in most industries. This problem remains today for most sectors in most developing countries. Without any corrective assistance and strategies, the only areas that are likely to grow in a free-market economy are sectors which have already achieved international competitiveness. In most developing countries these are likely to be low technology and low value added sectors where the productivity gap with more advanced countries is likely to be low and the wage differential can more than compensate for this, giving the developing country a competitive advantage in these sectors. These are sectors like garment stitching, cut flowers, simple toy and shoe manufacturing or simple food processing and packaging. In the poorest developing countries technological capabilities may be absent even for the simplest technologies to take off.

In theory, there are two broad types of policy responses to this problem, with different governance requirements. Both are responses to a common underlying problem which we need to first understand. Low productivity levels in a country may explain why investments in many areas are not immediately profitable but do not necessarily explain why investment to raise productivity in these sectors does not take place. If productivity can be raised through investment, and if wages are low, high profits are assured over time and this should typically pay for the additional time and risk involved in raising productivity. If this is not happening, we need to look at the market failures that may be preventing private investors from raising the underlying productivity at an acceptable level of risk. Many different market failures can prevent optimal levels of investment in late developers (Arrow 1962; Murphy, et al. 1989; Stiglitz 1989b; Greenwald and Stiglitz 2006). A market failure that has recently received attention is that involved in financing 'discovery' in developing countries (Hausmann and Rodrik 2003). The products in which a country may have competitive advantage are not known ex ante and require an investor to make investments to discover the underlying capabilities of the country. In many cases the investor will lose money, but investment can still be sustained if there are high profits for investors who strike it lucky. But if new entrants can easily enter the sectors that have been 'discovered' they can bid up wages and raw material costs and wipe out the profits of the pioneers. The market failure is that it is not possible to protect the profits of the Schumpeterian investors in this case and the answer may be to provide carefully designed subsidies for startup firms in such contexts. This market failure assumes that there are innate competitive advantages that some countries have because they are better at producing some low technology products rather than others. Such innate advantages are not necessarily convincing for too many types of products and processes.

Other market failures may be even more serious in preventing investment in new sectors in developing countries. We know that if new technologies take time to learn, 
even if a country has a potential comparative advantage in a product it will not be immediately profitable (Khan 2000a). As a result, investors (whether private or public) will have to act as principals providing finance to firms, with managers and workers within these firms acting as agents undertaking the learning. Initially, the principals will be making a loss, but they expect to make a substantial profit eventually. In other words, learning, like innovation, requires some individuals to earn rents for a period, and like innovation, if these rents are mismanaged the outcome may be poor. The likelihood of success now depends on the effort the agents put in. In a world where contracts were perfectly enforced, investors could ensure that managers and workers receiving temporary rents will put in the optimal effort, and this would enable private investments to take place by making the risk involved acceptable. In reality, if contracts are difficult to enforce, it may be very difficult to enforce compulsions on firm-level agents. In these circumstances, private investors external to the firm may not be willing to take the risk of investing for productivity improvement. This is an example of a market failure that may condemn the developing country to low levels of investment in productivity-enhancing industries.

This brings us to the two types of responses to these problems of market failure constraining growth in developing countries. The first response is to respond to specific market failures with narrowly defined interventions that create incentives or compulsions to move the outcome closer to what a more efficient market may have achieved. For instance, subsidies to investors may help to compensate for the costs of discovery or the higher uncertainty they face as a result of unenforceable contracts. Indeed, this was the type of intervention that was very common in the 1950s and 1960 s as developing countries attempted to reverse their performance under colonialism. This strategy was in the end disappointing in many developing countries because the range of market failures which policy-makers tried to address were too broadly defined, and in most cases existing governance capabilities were not remotely sufficient to enforce the requirements for success with such a range of interventions. While there were some attempts to improve the governance capabilities required to effectively manage these interventions, these governance requirements were not sufficiently recognized at the time.

In the absence of a sufficient effort to develop these governance capabilities, interventions to correct market failures often resulted in poor outcomes in many countries. Figure 1 summarizes the relationship between corrections of market failures, rents and therefore the possibility of government failures of various types. By definition, any social attempt to correct a market failure creates new income flows and therefore rents. Indeed, the rents are potentially the mechanisms through which new incentives and compulsions are created. But for these rents to have the appropriate effect, governance capabilities are required that can enforce, withdraw or otherwise respond to the results. This does not mean that all rent seeking has to be ruled out, an impossible goal in any economy (Khan 2000b). The governance requirement is more modest, namely that the rent seeking does not disrupt the intervention to the extent that the net effect is low or negative. Many developing countries did not achieve this, and many rents that were created in the attempt to correct market failures were often wasted or captured by powerful groups who did not in the end deliver growth, or delivered insufficient growth. 


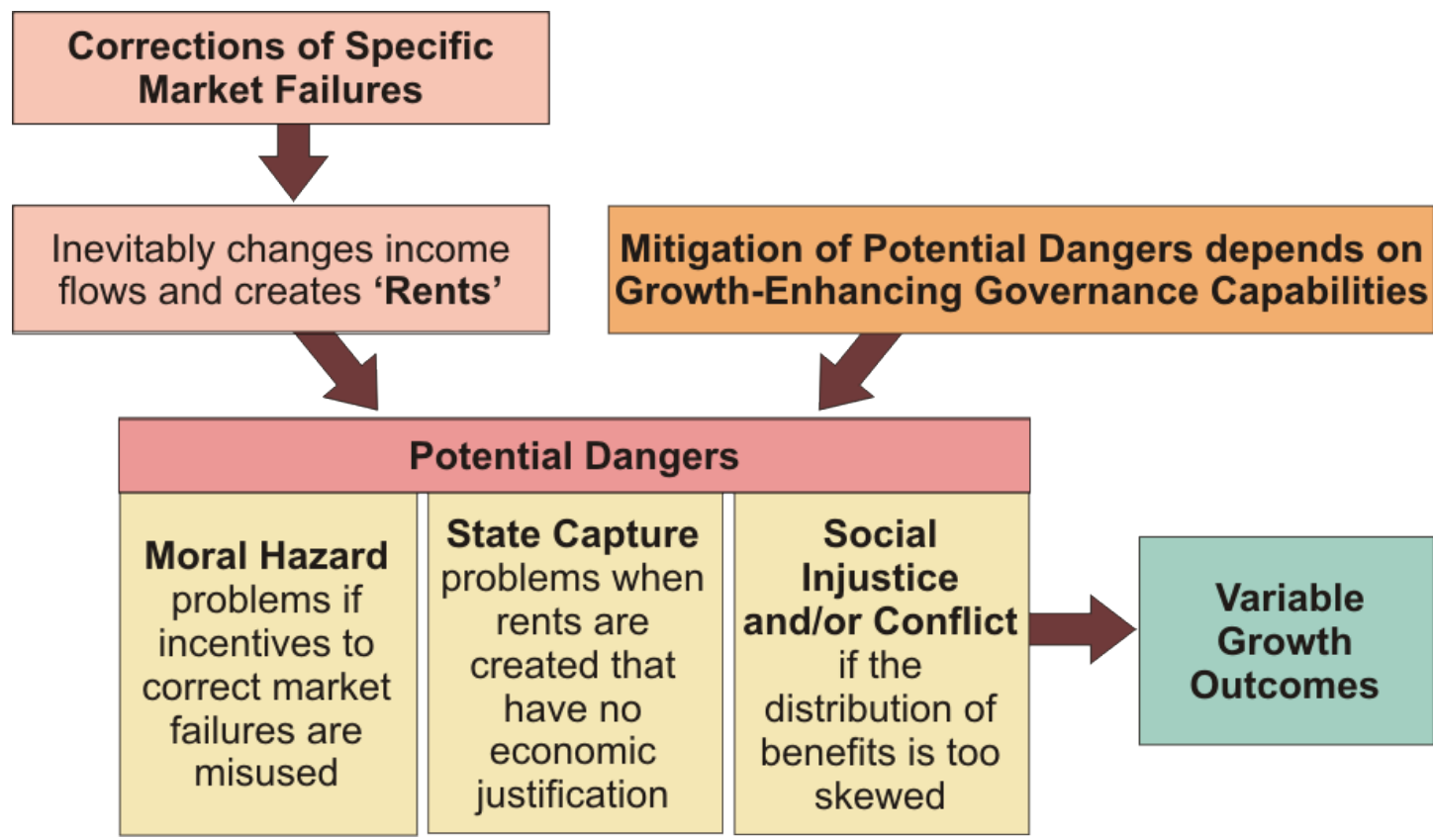

Figure 1 Growth requires specific Growth-Enhancing Governance Capabilities

Policies to correct specific market failures can result in a number of types of problems. First, there is a problem of moral hazard where policy creates some new benefits for some market participants but fails to achieve the desired policy goal. For instance, subsidies to assist training or making credit lines available to new startup companies to overcome capital market failures may simply be wasted without achieving the desired result. For this not to happen, governance capabilities of oversight and policy withdrawal are required so that the rents are not permanent and may be withdrawn if results are not achieved. The more narrowly defined the policy, the more plausible it may be to develop the governance capability to administer the policy reasonably effectively. A second problem is the policy-making agencies of government may get captured by rent seekers who may engineer solutions to market failures that do not really exist, simply to benefit from the rents created as a result. Limiting these possibilities require governance capabilities and political arrangements for ensuring that state capture cannot reach damaging proportions.

Finally, policy responses to market failures may be politically controversial because the solutions to market failures may benefit particular constituencies or groups. The same market failure can be addressed by many different policy approaches with different distributions of benefits. For instance, environmental pollution can be addressed by taxing the emitter of pollution, by subsidizing the polluter not to emit, by regulatory limits on emission, or by creating property rights on emissions so they become tradable. Each solution has different transaction costs and therefore chances of success, but more significantly, has different distributions of benefits, even if the net social benefit of addressing the externality is the same in all solutions. What this suggests is that if in a particular solution the distribution of net benefits is excessively adverse for powerful or significant groups in society, or if they have significantly adverse welfare implications on marginal groups, then even if the policy enhances growth overall there may be resistance and opposition that in turn will have social costs in the form of conflict. Once again, success in solving specific market failures requires governance capabilities to ensure that the policies that are adopted do not 
have excessively damaging political consequences in that specific context. The growth outcomes, satisfactory or otherwise thus depend both on the types of policies that seek to address market failures as well as on the governance capabilities that limit the possibility of government failures.

Instead of responding to this experience with the conclusion that perhaps the range of interventions needed to be scaled back in some of the less dynamic countries to target critical market failures, and that critical governance capabilities needed to be developed, the response from the late 1970s onwards was to persuade poorly performing developing countries to abandon all attempts to address their market failures through specific interventions. The new strategy was to address market failures by making markets more efficient across the board. The two prongs of the new 'market-fundamentalist' strategy were to remove interventions (liberalization) combined with the development of governance capabilities that aimed to reduce market failures by making markets more efficient. This approach is summarized in Figure 2.

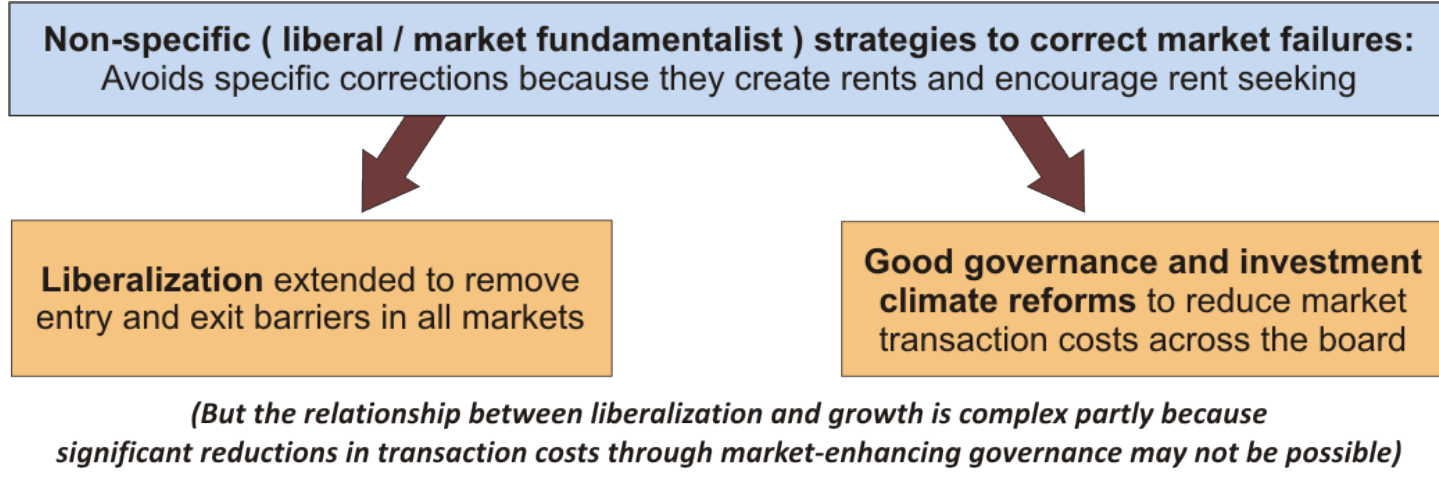

Figure 2 The Liberal/Good Governance Approach

And so paradoxically liberal policy-makers began to incorporate the importance of the state and of governance capabilities into the reform agenda. But it was explicitly understood that the governance capabilities to be developed or strengthened were the ones necessary for the creation of efficient markets, not the capacities required to address market failures. While we agree that the results of intervention in many developing countries in the 1960s were disappointing, we draw a different set of conclusions about policy priorities. Interventionist strategies in the 1960s and 1970s were disappointing in many developing countries because the market failures were not carefully identified, and the interventions were over-ambitious and not tailored to the feasible governance capabilities of particular countries. Yet these strategies did succeed dramatically in a few countries which for historic accidents had the appropriate governance capabilities to enforce the strategies they had embarked on. The lesson we wish to learn from the history of our experiences with both the interventionist strategies of the 1960s and the more recent history of good governance reforms of the 1990s is that neither address the pressing problems of triggering and sustaining growth and development in poor countries. An alternative growthpromoting governance strategy is to promote sequential and specific governance improvements tailored to effectively implement limited strategies that aim to overcome specific growth constraints in developing countries. Such an incremental growth-promoting governance strategy is most important for the least developed 
countries given their limited capacities for making significant progress in the medium term on ambitious generalized governance improvement strategies (Khan 2008a). This does not at all suggest that good governance reforms should be abandoned, but that the acceleration and sustaining of growth requires serious attention to an alternative set of governance goals.

\section{Good governance: The theory}

The consensus behind the good governance agenda draws heavily on a large body of theoretical contributions that are part of the New Institutional Economics that emerged in the 1980s (North 1984; Matthews 1986; North 1990, 1995; Clague, et al. 1997; Olson 1997; Bardhan 2000; Acemoglu, et al. 2004). The main theoretical links identified in New Institutional Economics that explain economic stagnation are summarized in Figure 3.

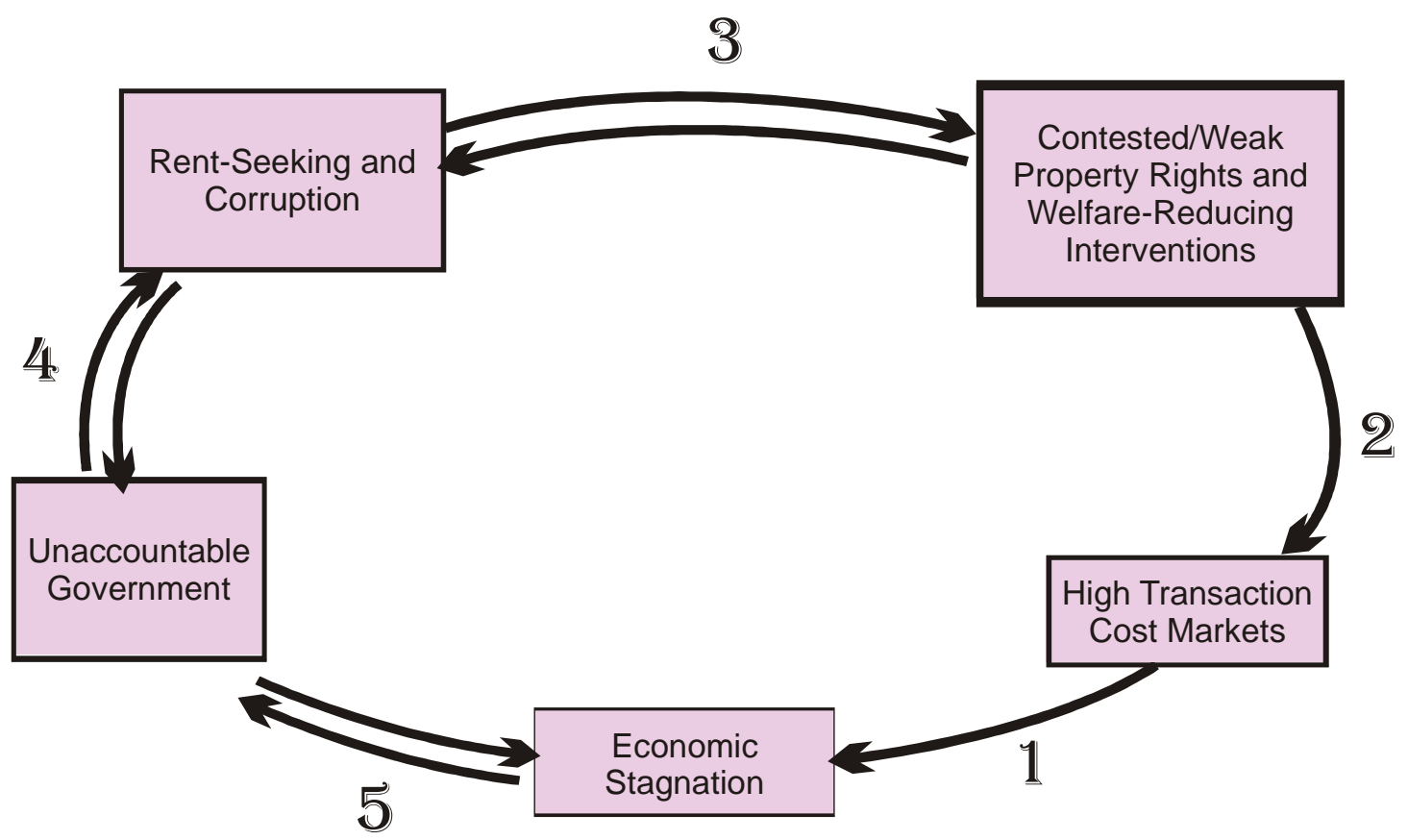

Figure 3 Theoretical linkages underpinning the good governance agenda

The fundamental link in all market-focused approaches is link 1 in Figure 3: economic stagnation and underdevelopment in poor countries is explained primarily by the persistence of inefficient markets. High transaction costs are simply a technical description of inefficient markets that suffer from extensive market failures. These high transaction costs are in turn explained by link 2: weak and contested property rights and unnecessary state interventions raise the costs of transacting in markets and create uncertainty which increases transaction costs. Unnecessary state interventions also create damaging rents signal lost economic opportunities. But link 3 shows that attempting to enforce property rights or to remove unnecessary government interventions will not work because these in turn are sustained by rent seeking and corruption, as privileged groups spend resources both legally and illegally to influence the state to distort property rights in their favour or create or distort interventions in their favour. There is a two-way causality here because weak property rights and welfare-reducing interventions also create incentives for rent seeking and corruption as individuals and groups try to work their way around these governance failures by bribing or influencing bureaucrats and politicians. Link 4 shows that rent seeking and 
corruption in turn are sustained because although very small groups of people benefit from these processes, the majority is unable to stop the damage these groups do because of the absence of accountable government. So to fight corruption and rent seeking it is also necessary to reform politics and improve democratic accountability. Again, link 4 shows a two-way causality because rent seeking and corruption can also be used to subvert democracy in favour of the interests of small groups.

During the time of the structural adjustment policies of the 1980s, the focus of reform was limited to link 2 in Figure 3. At that time the belief was that by removing unnecessary state interventions the efficiency of markets would be enhanced. The expectation was that these reforms would suffice to make markets more efficient through link 1, as well as reduce rent seeking and corruption through link 3 in figure 4 as these links operate in both directions. The new governance agenda adds to this the necessity of directly fighting corruption and rent seeking, as well as pushing forward with accountability reforms. The new belief is that only by attacking all the links in Figure 3 simultaneously is it possible to break out of the low-level development trap that many poor countries find themselves in.

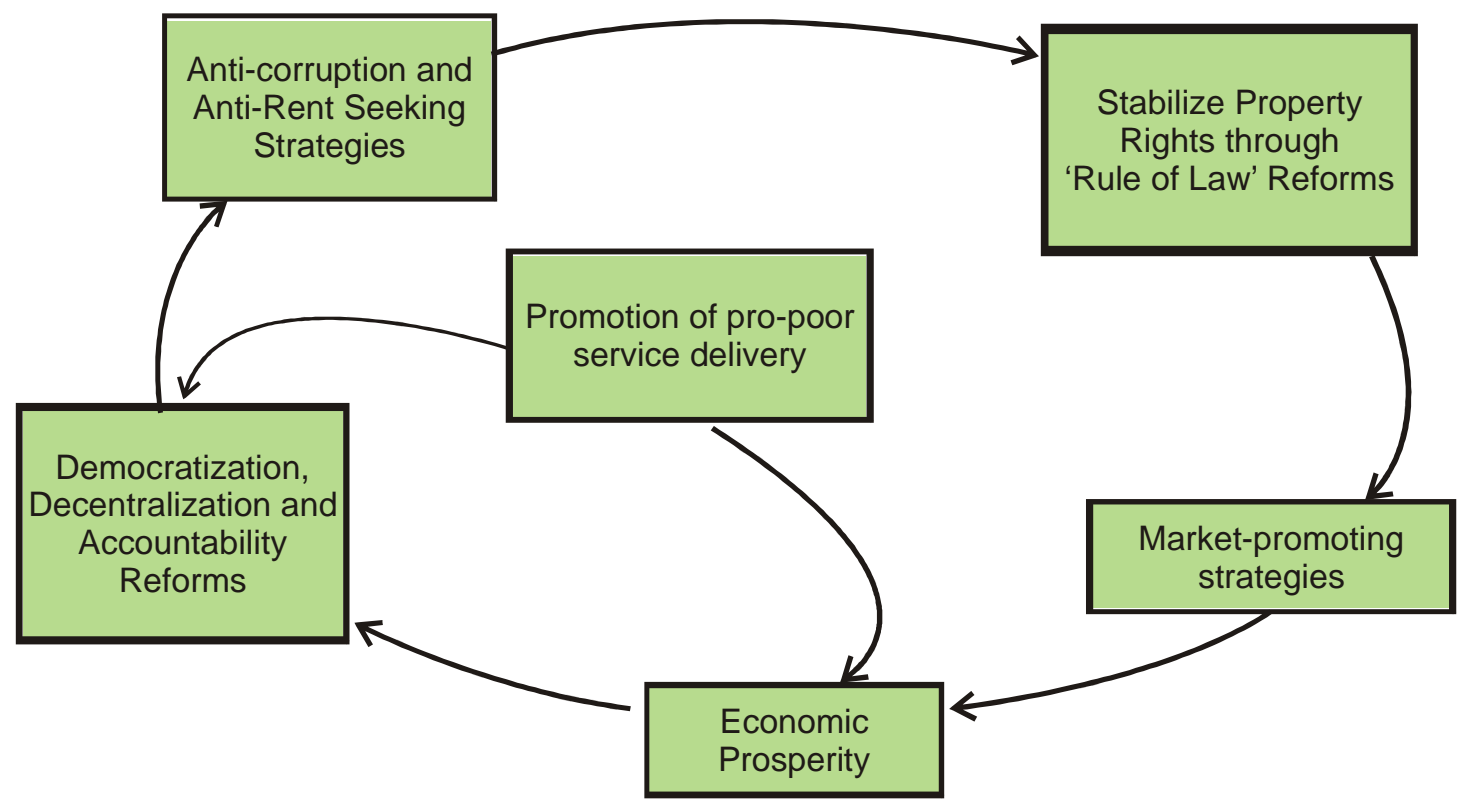

Figure 4 The Good Governance and Anti-Corruption Agenda

The multi-pronged policy agenda enshrined in the new good governance agenda is summarized in Figure 4. The new agenda suggests that unless all the links in figure 4 were simultaneously addressed, market efficiency would not improve. The logic was that property right instability and welfare-reducing interventions could not be attacked unless rent seeking and corruption were directly addressed, and in turn, these could not be significantly tackled unless the privileges of minorities engaged in rent seeking and corruption that harmed the majority could be challenged through accountability and democratization. In addition, to promote democratic accountability, donors argued that states in poor countries should be encouraged to deliver services to the poor. Western donors, particularly in Africa have taken the line that poor countries should prioritize pro-poor spending financed by aid where necessary, and the poor should be mobilized through democratic processes to ensure that the state effectively delivers these goods and services (such as primary education and health care). Though 
pro-poor service delivery directly tackles poverty, the broader case that is made for these reforms it that by empowering and raising the expectations of the majority (the poor), governments will become more accountable and this will feed into the broader governance reform agenda in the way shown in Figure 4.

At the same time, civil society groups in developing countries often support attempts to enforce these rules on the grounds that many are highly desirable goals regardless of their economic efficacy. And finally, the fiduciary responsibility of donor agencies to protect taxpayer funded aid programmes has driven donor concerns about corruption and the diversion of resources in developing countries. This too has provided support for anti-corruption strategies and for accountability reforms. The convergence of support from multiple constituencies who are at loggerheads on most other issues explains why support for this particular reform agenda is so deep-rooted and pervasive. Suggesting an alternative or even complementary governance agenda requires the construction of a new constituency that may be quite difficult to achieve compared to the broad constituency backing the good governance agenda.

A number of closely related measures of governance and approaches to reform have developed out of this framework, including the Doing Business surveys, Business Environment and Economic Performance surveys, and Productivity and Investment Climate surveys that are now produced by the World Bank and other agencies. These measure along different dimensions the degree to which states provide services that are consistent with market strategies. While there are differences between them, all of these measures fit in very well with the overall good governance agenda but look at micro-level indicators like the time it takes to get a telephone connection, the number of times a factory is visited by inspectors (the fewer the visits the better because inspections are assumed to create obstacles and provide opportunities for petty corruption), and business perceptions about the effectiveness of contract enforcement. What is common to all these measures is that there is no attempt to measure the success of a state in addressing market failures because it is assumed that any attempt to do so is itself counterproductive.

\section{The Evidence}

Support for the market-enhancing approach comes from cross-country regressions using measures of relevant governance capabilities to explain growth, often based on subjective assessments collected in surveys and expert opinions. An extensive academic literature has used this data to establish a positive relationship between market-enhancing governance conditions and economic performance (Knack and Keefer 1995; Mauro 1995; Barro 1996; Clague, et al. 1997; Knack and Keefer 1997; Johnson, et al. 1998; Hall and Jones 1999; Kauffman, et al. 1999; Lambsdorff 2005). This literature typically finds a positive relationship between the two, supporting the hypothesis that an improvement in market-enhancing governance conditions will promote growth and accelerate convergence with advanced countries. We will summarize some of the problems with approaches using governance indicators as these are well known and have been extensively discussed elsewhere (Arndt and Oman 2006; Carlin, et al. 2006; Khan 2007a; Meisel and Aoudia 2008).

The most important problem is that multiple directions of causality exist and are widely recognized. Even those who believe that market-enhancing governance capabilities have strong effects on growth also recognize that growth itself can 
provide greater resources for the provision of market-enhancing governance. Much of the econometric effort is in trying to resolve these directions of causality. Econometrics is not very good in determining causality in general, but in this case the data series for different aspects of market-enhancing governance are only available from the 1990s in any extensive form, making credible causality tests even more difficult. As an example, the general problem can be demonstrated with reference to a single indicator, that for the rule of law, shown in Figure 5. This is an important component of measures of market-enhancing governance capabilities, and part of the set of World Governance Indicators provided by the World Bank.

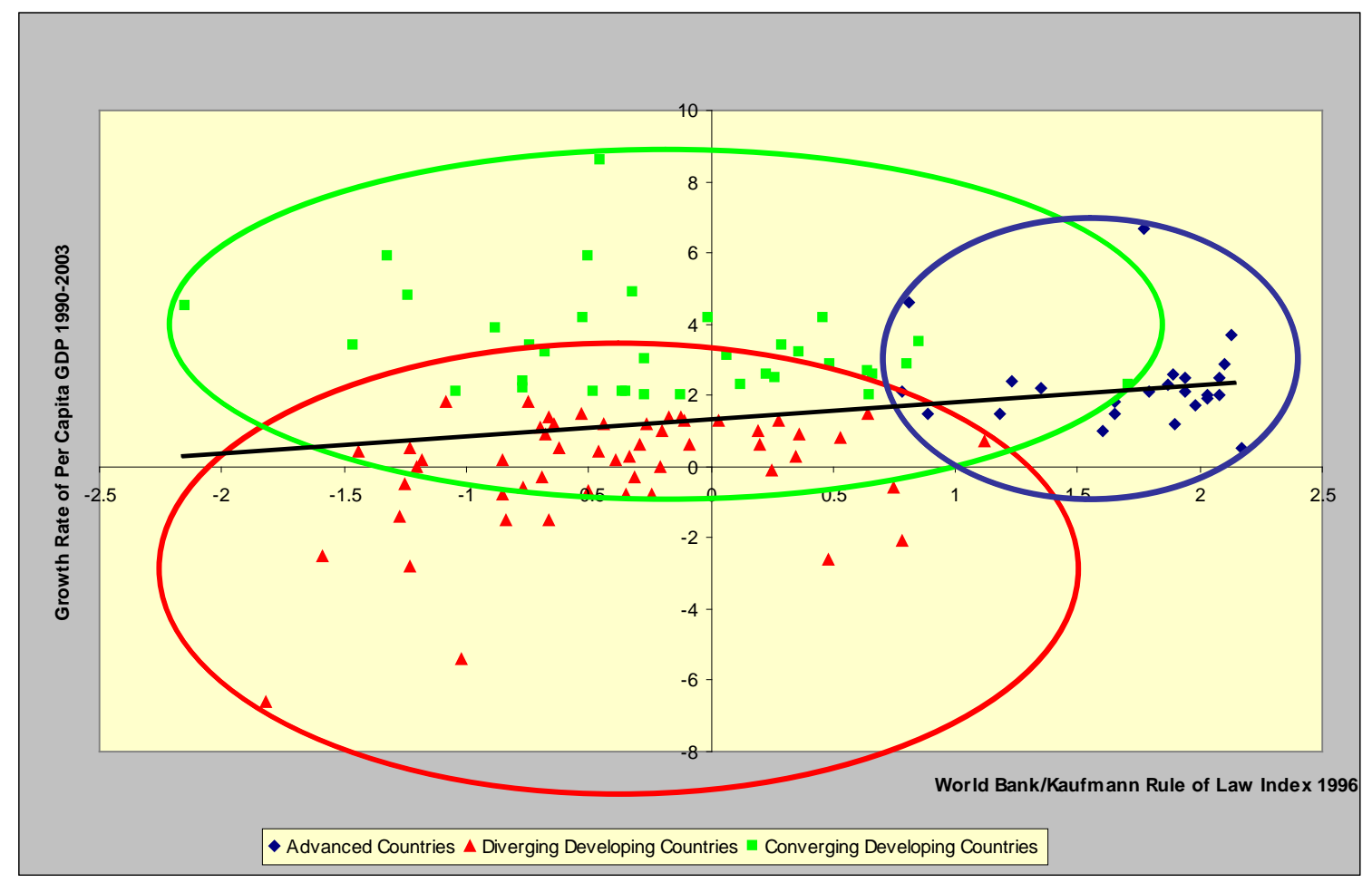

Figure 5 An Example of the Evidence: 'Rule of Law' and Growth 1990-2003

Without attempting any causality analysis, a visual examination of the data in Figure 5 suggests why sophisticated causality analysis on this type of data may be very misguided. If all the available data on the rule of law score for 1996 (the earliest available year) are plotted against growth rates for the 1990s we do indeed get the impression that better rule of law will result in higher growth rates. But once we distinguish between advanced and developing countries (to address the possibility of reverse causation since advanced countries are expected to have a better rule of law anyway) the picture becomes muddied. Diverging developing countries (with growth rates lower than the median advanced country growth rate) had virtually the same mean and dispersion of their rule of law indicators compared to the high growth converging developing countries (whose growth rates were higher than the median advanced country growth rate). In other words, performance on the rule of law indicator does not appear to distinguish high growth from low growth developing countries. The same pattern emerges when we look at corruption indicators, indicators for political accountability or indeed any indicator of market-enhancing governance (Khan 2004a, 2007a, 2008b). Of course there are many other variables determining growth differences between countries, but the governance indicators are 'deep' 
variables which are supposed to determine for instance the magnitude of investment and the efficiency of investment so if we fail to see any visual relationship at all it should alert us to some problem with the underlying hypothesis.

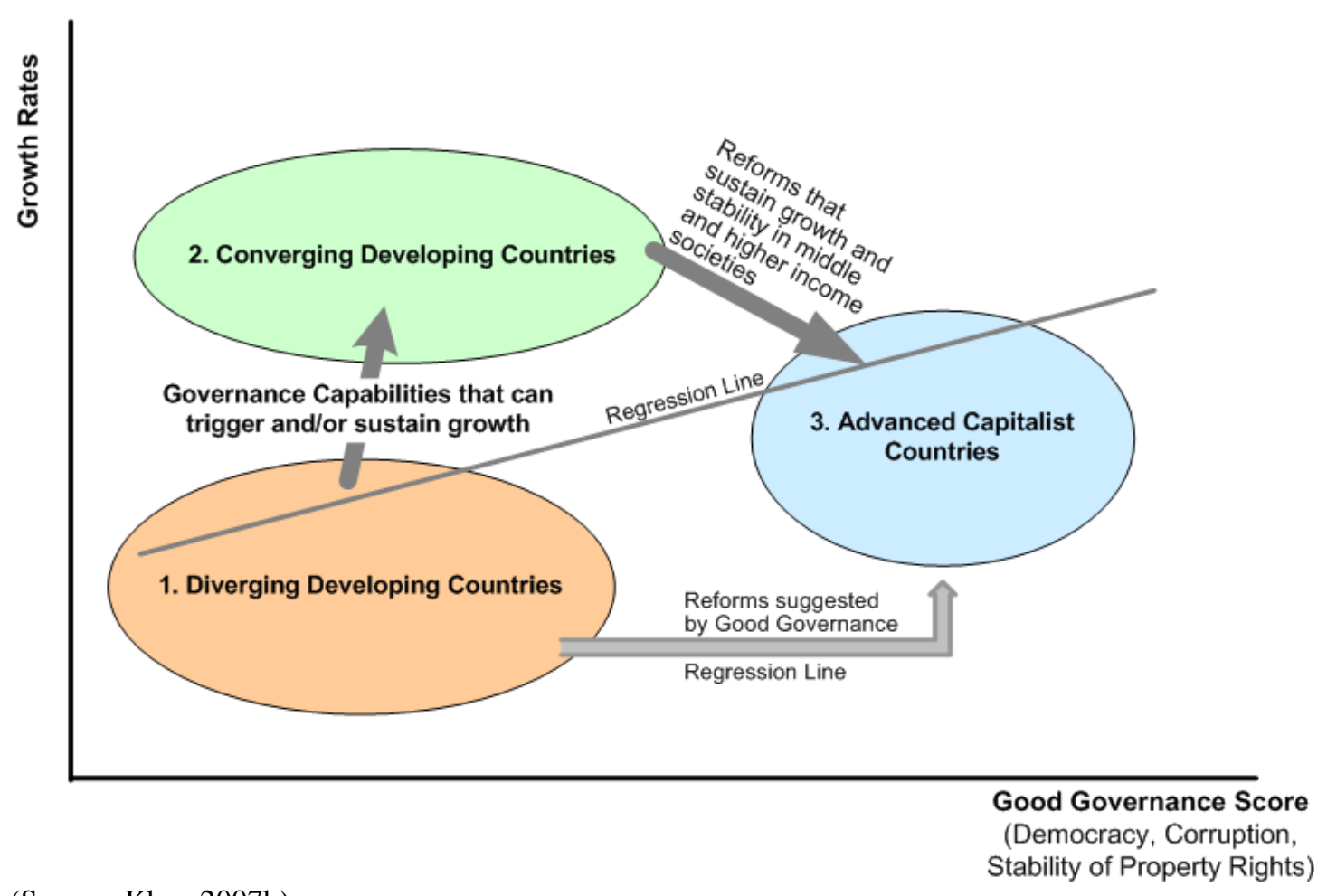

(Source: Khan 2007b)

Figure 6 Governance Characteristics of Growth Economies

Our interpretation of the general problem is summarized in Figure 6. The characteristics of advanced economies are not really interesting for developing countries, nor is there any historical process evidence that reforms of the type suggested by good governance resulted in countries from group 1 reaching group 3 . Our focus should rather be on group 1 and group 2 countries. Some critical governance capabilities allowed some group 1 countries to become high growth group 2 countries, but in general it was not superior scores on good governance indicators. We also know that group 2 economies include many different types of growth stories, some more sustainable than others. Some converging economies have significant growth-enhancing governance capabilities that allow them not only to grow fast for a while, but to sustain this growth and spread it across the economy to make a sustained transition to prosperity. The North East Asian countries were examples of countries with such governance capabilities. Other countries may be in the converging group because they have some sectors or regions or minerals which produce globally competitive products but they may be quite vulnerable unless further growthenhancing sectors and capabilities are developed.

The only thing that is clear is that developing countries do not in general solve the market failures that constrain their growth through good governance capabilities. In theory significant improvements in good governance characteristics may have helped to improve the efficiency of markets and thereby contributed to sustaining growth. But in reality such improvements are structurally beyond the reach of developing 
countries which are significantly below upper middle income status. The crosscountry empirical evidence strongly supports that conclusion (Khan 2007b, 2008b).

As the problems with supporting the good governance agenda using contemporary governance indicators are well known, attempts have been made to support the argument for good governance using instrumental variables and longer historical data. One of the most influential arguments frequently referred to in support of the good governance agenda comes from Acemoglu, Johnson and Robinson (Acemoglu, et al. 2001, 2002) henceforth AJR. But while their econometrics is impressive, they implicitly present an interpretation of history that is at variance with historical knowledge. The argument they develop is that 'bad' colonialism in non-settler colonies created unstable property rights because colonial powers in these countries were only interested in extracting resources. In contrast, they argue, 'good' colonialism in settler colonies created stable property rights because settlers wanted to live here and the result was prosperity. This comforting but deeply misleading narrative diverts our attention from the economics and politics of growth-enhancing property rights reform and the governance capabilities required by developing countries to sustain growth during their contemporary transitions.

AJR's innovation was to use exogenous proxy variables (settler mortality or low initial population density) as instruments for locating where white settlers settled and set up settler colonies. It has long been known that settler colonies did significantly better in achieving development than non-settler colonies. The problem that their instruments arguably correct for is that they ensure that the analysis does not pick up the possibility that white settlers settled in areas that had an advantage for some other reason. But in the end, their econometric sophistication says little more than something that is quite uncontroversial: white settler colonies did a lot better than other developing regions. The question is why? Here they make an assertion that has nothing to do with their econometrics. They assert that the reason was that settler colonies set up stable property rights while non-settler colonies set up extractive systems that disrupted property rights, apparently with lasting and persistent consequences. This reassuring version of colonial history, summarized in Figure 7, is becoming increasingly accepted as having been proved by their econometric exercise.

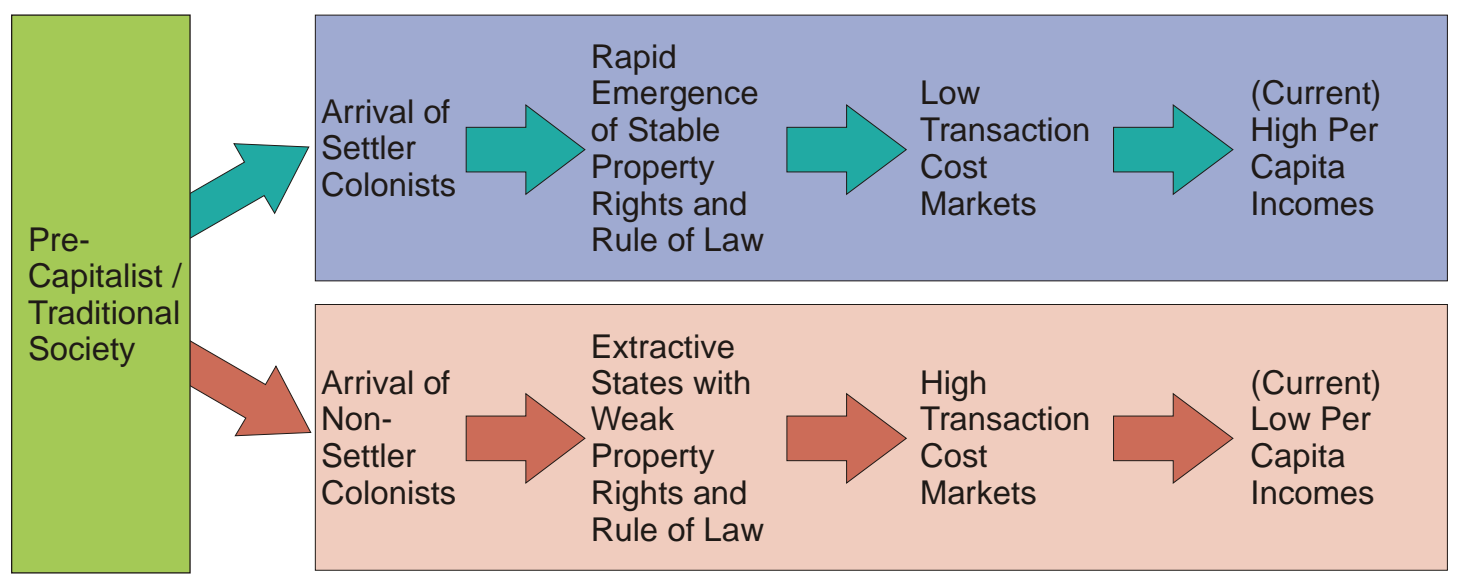

Figure 7 The Acemoglu et al. Version of Colonial History

Source: (Khan 2009: Figure 7) 
In fact, nothing of the sort is actually demonstrated in their work. All that their work demonstrates is that settler colonies ended up with significantly higher per capita incomes and higher scores in property rights stability a century or so later. AJR present no conclusive argument that the eventual outcomes were achieved because these states first established stable property rights and set up limited government. In reality, as Glaeser et al. point out, the same evidence could be used to argue that what the settlers brought with them was primarily their human capital (that is themselves) rather than their institutions, which arguably developed much later (Glaeser, et al. 2004). What is worse, since the acquisition of human capital is in the long run a policy choice, a sophisticated racist could use the AJR evidence to argue that the superior performance of white settler colonies demonstrates the genetic advantage of whites in acquiring human capital (or indeed in setting up good institutions). AJR's regressions only establish that white settler colonies did better (which no-one questioned anyway), and that where white settlers settled probably had little to do with the pre-settler productivity of the region. However, AJR's own work shows that settler colonies were more likely to be set up in areas where indigenous populations were not dense (Acemoglu, et al. 2002). But they failed to pick up the significance of this for the historical processes through which social transformations were achieved.

If anything, AJR's story of expropriation can be turned on its head for the early period of colonialism in settler and non-settler colonies. The most obvious and striking fact about settler colonialism is the qualitatively more violent process that was unleashed on indigenous populations, verging on and in some cases amounting to genocide. The Belgian Congo was a possible exception to the rule that non-settler colonies faced lower levels of violence compared to settler colonies. In the non-settler colonies the colonial power faced dense populations that were relatively well organized and they immediately made complex political compromises with pre-existing and new elites to sustain colonial rule. In contrast, in settler colonies pre-existing populations were thinly spread out and the consequences of this turned out to be devastating for them. It meant that settlers could follow much more aggressive military strategies of land grabbing and destruction of pre-existing rights. Here indigenous populations faced dramatic and rapid expropriation of their lands, were pushed into smaller and smaller pockets of territories and in many cases suffered precipitous collapses in numbers that in some cases amounted to genocide.

In North America the size of the 'pre-contact' American Indian population has been the subject of debate but the fact of its precipitous decline into near disappearance and the rapid and largely uncompensated loss of American Indian communal land rights is not (Snipp 1989; Sale 1990; Stiffarm and Lane Jr. 1992; Stannard 1993). In South Africa, the militarism and unwillingness to compromise that is evident for instance in the writings of Lord Garnet Wolseley during the Zulu Wars is in stark contrast to the strategies the British followed in India (Gump 1996; Lieven 1999). Indeed, Lieven's description of the uncompromising 'total war' the British waged against the Zulus and their economy has elements of similarity with the German genocide of the Herrero people in neighbouring south-west Africa (Lieven 1999: 631) In Australia there is an explicit discourse of genocide to describe what happened to the aboriginal population (Tatz 1999; Moses 2000). Violence against aboriginal peoples in Australia was directly related to settler demand for land and the need to clear the land of the huntergatherer aborigines. The simple expedient was to deny any recognition of prior rights. The forceful exclusion of aboriginal peoples from their livelihoods led to precipitous 
population declines, in some areas by as much as 80 per cent (Moses 2000). To describe these processes in terms of the settler states establishing a rule of law and stable property rights clearly does huge injustice to our understanding of history and is at least manifestly economical with the truth.

The inconvenient truth about the settler colonies summarized in Figure 8 is that they did indeed make a transition to 'stable property rights' but only after the rights inappropriate for the new capitalist economies were thoroughly destroyed. Settlers from already capitalist countries came with ideas of how to organize production but they did not try to work with pre-existing rights, defining them better, creating markets and a rule of law and then trying to re-allocate assets through voluntary contracts in markets. Instead, the transitions here were not periods of stable property rights but the absolute reverse. They were periods of systematic, widespread and violent destruction of almost all pre-existing rights because these rights did not serve the interests of settlers who were setting up capitalist economies in their own interest. Thus, this sophisticated econometric attempt to establish causality fails because its claim that stable property rights explain the higher growth of settler colonies does not stand up to the scrutiny of historical process. The social and economic transformation that created the preconditions for growth in settler colonies was carried out entirely outside the framework of a rule of law and a market economy based on contractual transfers of assets. The emergence of stable property rights, contracts and political accountability emerged in these societies after the critical transformations in economic, social and political structures had already been carried out, in these cases through processes of enormous violence.

\begin{tabular}{|c|c|c|c|c|c|}
\hline \multirow{2}{*}{$\begin{array}{l}\text { Pre- } \\
\text { Capitalist / } \\
\text { Traditional } \\
\text { Society }\end{array}$} & $\begin{array}{l}\text { Arrival of } \\
\text { Settler } \\
\text { Colonists }\end{array}$ & $\begin{array}{l}\text { TRANSITION } \\
\text { COMPLETED: } \\
\text { Pre-existing rights } \\
\text { destroyed through } \\
\text { intense conflict } \\
\text { Transition costs } \\
\text { Very High }\end{array}$ & $\begin{array}{l}\text { Rapid } \\
\text { transfer of } \\
\text { assets } \\
\text { with new } \\
\text { rights } \\
\text { creates a } \\
\text { capitalist } \\
\text { economy }\end{array}$ & $\begin{array}{l}\text { Rights required } \\
\text { to drive growth } \\
\text { emerge: } \\
\text { Growth- } \\
\text { constraining } \\
\text { transaction } \\
\text { costs fall }\end{array}$ & $\begin{array}{l}\text { High Per } \\
\text { Capita } \\
\text { Incomes } \\
\text { Today }\end{array}$ \\
\hline & $\begin{array}{l}\text { Arrival of } \\
\text { Non- } \\
\text { Settler } \\
\text { Colonists }\end{array}$ & $\begin{array}{l}\text { PROLONGED } \\
\text { INCOMPLETE } \\
\text { TRANSITION: } \\
\text { Many pre-existing } \\
\text { rights protected } \\
\text { Transition Costs } \\
\text { Moderate to Low }\end{array}$ & $\begin{array}{l}\text { Pre-capitalist } \\
\text { and 'anti- } \\
\text { capitalist' } \\
\text { rights } \\
\text { sometimes } \\
\text { strengthened } \\
\text { but pockets } \\
\text { of capitalism } \\
\text { emerge }\end{array}$ & $\begin{array}{l}\text { Capitalist } \\
\text { transition } \\
\text { incomplete: } \\
\text { Growth- } \\
\text { constraining } \\
\text { transaction } \\
\text { costs remain } \\
\text { moderate to } \\
\text { high }\end{array}$ & $\begin{array}{l}\text { Lower Per } \\
\text { Capita } \\
\text { Incomes } \\
\text { Today }\end{array}$ \\
\hline
\end{tabular}

Figure 8 Colonial History’s Inconvenient Truths

Source: (Khan 2009: Figure 8).

Paradoxically, pre-existing property rights were much better protected in the nonsettler colonies. For instance, Austin argues that in Ghana the colonial state supported productive African property rights and intervened to moderate monopsonistic behaviour by European commodity purchasers (2008: 1011). However, Austin's examples of support for productive African property rights can also be interpreted as a demonstration of the willingness of the colonial power to support conflicting sets of rights out of political expediency. Thus, Austin provides an example where the British colonial power supported the rights of cocoa planters to the trees they had planted 
under indigenous Akan land law even when the land did not belong to the chief of the planters. At the same time, the traditional rights of the chiefs were left intact.

The complex political constraints driving colonial land property policy is even more obvious in the example of the British West Africa Lands Policy when British policy suddenly changed from supporting individual ownership of land in Lagos in 1861 to a newly discovered preference for 'traditional' land tenure in the Nigerian territories acquired between 1892 to 1903 (2008: 1009). The shift to a form of property right that was theoretically inferior for a capitalist transition cannot be explained by the presence of an extractive state of the Acemoglu et al. type since the non-settler colonial power had supported individual property rights in the immediate past and it is not at all clear how traditional land rights would allow more expropriation. A more plausible explanation is that the thinning out of British military power as its territories expanded led colonial administrators to prioritize the avoidance of social conflict and to seek to retain the support of the broadest possible definition of 'traditional elites'.

Consistent with this interpretation, a growing body of literature has corroborated critical aspects of Mamdani's (1997) analysis of the 'bifurcated state'. This argued that traditional or customary forms of tenure in Africa are largely colonial creations that had tenuous roots in pre-colonial history. The colonial power artificially created 'customary authorities' as a method of exercising social, political and administrative control in a context where direct rule was difficult given the military and demographic disadvantage faced by colonial administrators in non-settler colonies. In these cases, colonial powers created new rights for the constituencies they needed, not for expropriating resources but to achieve political control in a context where they had limited roots in indigenous society. This perspective is supported by a considerable body of corroborating evidence (Chimhowu and Woodhouse 2006). Clearly the recognition of traditional rights aimed to draw in different layers of traditional elites located in pre-colonial power structures. It is not surprising that non-settler colonial powers very often created conflicting and incoherent rights that could impede economic transformations.

The analysis of settler versus non-settler colonialism is important for contemporary policy for several reasons. First, a historical understanding of the problems created by colonialism suggests that the challenge facing contemporary developing countries is not to create through good governance the stable property rights that settler colonies apparently created. A rapid creation of such rights is precluded once we understand what that would entail in terms of transition costs. Once these are taken into account, the settler colonies should serve as models of what not to do, because they solved the problem with a degree of violence that cannot be recommended today and was not justified in the past. If developing countries today are not following the example of settler colonies and moving rapidly in the direction of capitalist property rights it is not because they necessarily lack the political will, but more likely because they implicitly understand the issue of transition costs.

Secondly, the long history of non-settler colonial rule has also left serious problems in the form of social engineering that created a multitude of rights and social entitlements that were inappropriate for asset re-allocations and for creating the productivity compulsions necessary for driving growth (Khan 2009). Finally, in the nineteenth century when settler economies were being set up, the technological gap 
between leader and follower countries was not so great that significant market failures constrained investments particularly in the agricultural sectors of the settler colonies. Nevertheless, even at that early stage, the manufacturing takeoff needed tariffs and protection in settler colonies like the United States (Greenwald and Stiglitz 2006). The refusal of non-settler colonial administrations in places like India to allow significant tariff protection for domestic manufactures till the early twentieth century resulted in the relative deindustrialization of India and its falling behind that we referred to earlier. In other words, there were significant differences in the growth strategies followed by settler and non-settler colonies but the differences had little to do with the mythology that settler colony growth was driven by their respect for property rights, rule of law and a minimal state. Yet, stable property rights and a rule of law did develop faster and deeper in the settler colonies as their capitalist sectors grew, became economically viable and started paying significant taxes that paid for their protection.

Given the ahistorical governance advice that developing countries in Africa and elsewhere have received, it is not surprising that progress has been limited. The contemporary good governance agenda identifies areas of policy priority that are hard to justify on the basis of the historical evidence of capabilities and strategies of rapid developers in Asia and elsewhere. It is important to understand that we are talking about sequences and priorities. We are not saying that improving political accountability, fighting corruption or improving the rule of law is not a set of desirable goals for any society. Even if we all agree that these are desirable objectives, we still have to answer the question: how are we going to implement and achieve these governance capabilities? The answer may be that we need to achieve some intermediate and immediate growth-promoting governance capabilities to sustain growth which will eventually provide the resources to improve some of these marketenhancing governance capabilities as well as achieve other developmental objectives.

\section{Growth-Enhancing Governance and Economic Growth}

The historical evidence from Asia and elsewhere suggests that transitions to development have required strong state capabilities for dealing with critical market failures. The historical evidence that is available suggests that none of these countries would have passed the good governance test at early stages of their development and transformation. The role of the state in the 'statist' transitions in East Asian countries is widely recognized but liberal economists argue that these experiences cannot be replicated in other countries. If replication means the reproduction of any particular country's blueprint in another, we would agree. But recent attempts to present settler colonies as examples of transitions driven by stable property rights and limited government are historical misrepresentations. In fact transitions in all countries required significant non-market activities by states and what is more, the degree of violence and injustice was significantly greater in the settler colonies compared to the East Asian examples. As strategies of transformation there is little to recommend the settler colonies. While no historical example provides a blueprint for contemporary societies, the growth-enhancing governance approach aims to identify broad structural problems that historical transitions addressed so that contemporary societies can address the problems of social transformation with greater social justice and with fewer costly mistakes. 
In understanding the challenges facing Africa, we need to keep in mind the structural features of developing countries that require the development of growth-enhancing governance capabilities (Khan 2004b, 2005). These are capabilities that give states an ability to deal with critical market failures that in broad outline have faced all developing countries. Two areas in particular stand out as requiring close attention and country-specific responses. First, developing countries require governance capabilities to manage property rights over many valuable resources that will remain weakly defined during early stages of development. Historical evidence and theory suggest that contrary to good governance theory, the weakness of property rights in developing countries is structural and not entirely due to the extractive greed of political leaderships or their inadequate political will to enforce the rule of law. It is very expensive to protect property rights and enforce contracts to an extent that would allow most asset re-allocations to be organized through markets. The historical examples of successful development demonstrate that in the meantime, significant state capabilities for achieving vital asset allocations through non-market processes were vitally important. The differences between countries have been in their effectiveness, and in the degree of injustice and violence that was involved. The challenge is to achieve capabilities for allowing industrial and agricultural development through land allocation and other asset allocation strategies that achieve greater efficiency than existing high transaction cost markets together with as much justice as possible through fair levels of compensation and consensus building about social objectives.

Secondly, market-led development is typically constrained by a variety of market failures that prevent investment in potentially high value sectors and the absorption, adaptation and learning of more advanced technologies. In particular, entrepreneurs face a structural problem in acquiring the tacit knowledge and learning required for using modern technologies essential for achieving international competitiveness. Achieving these capabilities requires complementary governance capabilities on the part of the state to manage incentives and opportunities for technological catching up, while creating compulsions for entrepreneurs not to waste resources. Countries differ widely in these capabilities, and therefore in their capacities to absorb new technologies rapidly. The experience of East Asia shows that the relevant state capabilities differed widely because the underlying strategies of technology acquisition were also significantly different between countries depending on their initial conditions of entrepreneurial abilities and technological trajectories.

Technology acquisition strategies and complementary governance capabilities ranged from governments being able to effectively discipline subsidies for technology acquisition as in South Korea, licensing new technologies and providing them to the private sector as in Taiwan or attracting higher technology multinationals with appropriate incentives and conditions as in Malaysia (Khan 2000b; Khan and Blankenburg 2009). In each case strategies were more or less successful depending on the governance capabilities of the respective states to implement these strategies effectively. Very similar strategies failed to deliver good results in other developing countries because the appropriate governance capabilities for implementation were missing. Clearly, the initial conditions are more adverse in some African countries in terms of entrepreneurial skills and knowledge of technologies compared to the high growth Asian countries in the 1960s. Nevertheless, opening up markets and making the relatively small improvements in market-enhancing governance conditions that 
are feasible are clearly not going to work in terms of attracting the necessary investments in learning and technology adoption. Identifying feasible strategies of building growth-enhancing governance capabilities in Africa based on these types of insights from historical evidence are likely to be more useful than the generalized good governance approaches that developing countries have been following.

\section{References}

Acemoglu, Daron, Simon Johnson and James A. Robinson 2001. The Colonial Origins of Comparative Development: An Empirical Investigation, American Economic Review 91 (5): 1369-401.

Acemoglu, Daron, Simon Johnson and James A. Robinson 2002. Reversal of Fortune: Geography and Institutions in the Making of the Modern World Income Distribution, The Quarterly Journal of Economics 117 (4): 1231-94.

Acemoglu, Daron, Simon Johnson and James A. Robinson 2004. Institutions as the Fundamental Cause of Long-Run Growth. Working Paper No. 10481. National Bureau of Economic Research: Cambridge Mass. Available HTTP: $<$ http://www.nber.org/papers/w10481>

Arndt, Christiane and Charles Oman 2006. Uses and Abuses of Governance Indicators, Development Centre of the Organisation for Economic Co-Operation and Development (OECD). Paris: OECD.

Arrow, Kenneth J. 1962. The Economic Implications of Learning by Doing, The Review of Economic Studies 29 (3): 155-73.

Austin, Gareth 2008. The 'Reversal of Fortune' Thesis and the Compression of History: Perspectives from African and Comparative Economic History, Journal of International Development 20 (8): 996-1027.

Bardhan, Pranab 2000. The Nature of Institutional Impediments to Economic Development, in Olson, Mancur and Satu Kähkönen (eds) A Not-so-Dismal Science: A Broader View of Economies and Societies, Oxford: Oxford University Press.

Barro, Robert J. 1996. Democracy and Growth, Journal of Economic Growth 1 (1): 127.

Carlin, Wendy, Mark E. Schaffer and Paul Seabright 2006. Where are the Real Bottlenecks? A Lagrangian Approach to Identifying Constraints on Growth from Subjective Data. Centre for Economic Reform and Transformation Discussion Paper No. 2006/04. Heriot-Watt University: Edinburgh. Available HTTP: $<$ http://www.sml.hw.ac.uk/cert> 
Chimhowu, Admos and Phil Woodhouse 2006. Customary vs Private Property Rights? Dynamics and Trajectories of Vernacular Land Markets in Sub-Saharan Africa, Journal of Agrarian Change 6 (3): 346-71.

Clague, Christopher, Philip Keefer, Stephen Knack and Mancur Olson 1997. Democracy, Autocracy and the Institutions Supportive of Economic Growth, in Clague, Christopher (ed.) Institutions and Economic Development: Growth and Governance in Less-Developed and Post-Socialist Countries, Baltimore: The Johns Hopkins University Press.

Clark, Gregory and Susan Wolcott 2002. One Polity, Many Countries: Economic Growth in India, 1873-2000, in Rodrik, Dani (ed.) Institutions, Integration, and Geography: In Search of the Deep Determinants of Economic Growth, Princeton NJ: Princeton University Press. Available HTTP: $<$ http://ksghome.harvard.edu/ .drodrik.academic.ksg/Growth\%20volume/ClarkIndia.pdf $>$

Glaeser, Edward L., Rafael La Porta, Florenico Lopez-de-Silanes and Andrei Shleifer 2004. Do Institutions Cause Growth?, Journal of Economic Growth 9 (3): 271-303.

Greenwald, Bruce and Joseph E. Stiglitz 2006. Helping Infant Economies Grow: Foundations of Trade Policies for Developing Countries, American Economic Review 96 (2): 141-46.

Gump, James O. 1996. The Dust Rose Like Smoke: The Subjugation of the Zulu and the Sioux. Lincoln: University of Nebraska Press.

Hall, Robert and Charles Jones 1999. Why Do Some Countries Produce So Much More Output Per Worker Than Others?, Quarterly Journal of Economics 114 (1): 83116.

Hausmann, Ricardo and Dani Rodrik 2003. Economic Development as Self Discovery, Journal of Development Economics 72 (2): 603-33. Available HTTP: $<$ http://ksghome.harvard.edu/ drodrik/selfdisc.pdf $>$

Johnson, Simon, Daniel Kaufmann and Pablo Zoido-Lobatón 1998. Regulatory Discretion and the Unofficial Economy, American Economic Review 88 (2): 387-92.

Kauffman, Daniel, Aart Kraay and Pablo Zoido-Lobatón 1999. Governance Matters. World Bank Policy Working Paper No. 2196. World Bank: Washington.

Khan, Mushtaq H. 2000a. Rents, Efficiency and Growth, in Khan, Mushtaq H. and K.S. Jomo (eds) Rents, Rent-Seeking and Economic Development: Theory and Evidence in Asia, Cambridge: Cambridge University Press.

Khan, Mushtaq H. 2000b. Rent-seeking as Process, in Khan, Mushtaq H. and K.S. Jomo (eds) Rents, Rent-Seeking and Economic Development: Theory and Evidence in Asia, Cambridge: Cambridge University Press. 
Khan, Mushtaq H. 2002. Corruption and Governance in Early Capitalism: World Bank Strategies and their Limitations, in Pincus, Jonathan and Jeffrey Winters (eds) Reinventing the World Bank, Ithaca: Cornell University Press.

Khan, Mushtaq H. 2004a. State Failure in Developing Countries and Strategies of Institutional Reform, in Tungodden, Bertil, Nicholas Stern and Ivar Kolstad (eds) Annual World Bank Conference on Development Economics Europe (2003): Toward Pro-Poor Policies: Aid Institutions and Globalization, Proceedings of Annual World Bank Conference on Development Economics, Oxford: Oxford University Press and World Bank. $\quad$ Available HTTP: $\quad<$ http://wwwwds.worldbank.org/servlet/WDS_IBank_Servlet?pcont=details\&eid=000160016_200 $\underline{40518162841>}$

Khan, Mushtaq H. 2004b. Strategies for State-Led Social Transformation: RentManagement, Technology Acquisition and Long-Term Growth, in Asian Development Bank and Vietnam Development Forum (eds) Which Institutions are Critical to Sustain Long-Term Growth in Vietnam?, Hanoi: Asian Development Bank.

Khan, Mushtaq H. 2005. The Capitalist Transformation, in Jomo, K.S. and Erik S. Reinert (eds) Development Economics: How Schools of Economic Thought Have Addressed Development, London and New Delhi: Zed Press and Tulika.

Khan, Mushtaq H. 2006. Determinants of Corruption in Developing Countries: the Limits of Conventional Economic Analysis, in Rose-Ackerman, Susan (ed.) International Handbook on the Economics of Corruption, Cheltenham: Edward Elgar.

Khan, Mushtaq H. 2007a. Governance, Economic Growth and Development since the 1960s, in Ocampo, José Antonio, K.S. Jomo and Rob Vos (eds) Growth Divergences: Explaining Differences in Economic Performance, Hyderabad, London and Penang: Orient Longman, Zed Books and Third World Network. Available HTTP: $<$ http://www.un.org/esa/desa/papers/2007/wp54_2007.pdf>

Khan, Mushtaq H. 2007b. Governance and Growth: A Preliminary Report. Research Paper supported by DFID grant. SOAS: London. Available HTTP: <http://mercury.soas.ac.uk/users/mk17/Docs/Preliminary\%20Report.pdf>

Khan, Mushtaq H. 2008a. Building Growth-Promoting Governance Capabilities. Background Paper for The Least Developed Countries Report 2008. UNCTAD: Geneva. Available HTTP:

$<$ http://mercury.soas.ac.uk/users/mk17/Docs/Building\%20Growth\%20Promoting\%20 Governance.pdf>

Khan, Mushtaq H. 2008b. Governance and Development: The Perspective of GrowthEnhancing Governance, in GRIPS Development Forum (ed.) Diversity and Complementarity in Development Aid: East Asian Lessons for African Growth, Tokyo: National Graduate Institute for Policy Studies. Available HTTP: <http://mercury.soas.ac.uk/users/mk17/Docs/GRIPS.pdf $>$

Khan, Mushtaq H. 2009. Governance Capabilities and the Property Rights Transition in Developing Countries. DFID Research Paper Series on Governance for Growth. 
School of Oriental and African Studies, University of London: London. Available HTTP:

$<$ http://mercury.soas.ac.uk/users/mk17/Docs/Property\%20Transitions\%20internet.pdf $>$

Khan, Mushtaq H. and Stephanie Blankenburg 2009. The Political Economy of Industrial Policy in Asia and Latin America, in Dosi, Giovanni, Mario Cimoli and Joseph E. Stiglitz (eds) Industrial Policy and Development: The Political Economy of Capabilities Accumulation, Oxford: Oxford University Press.

Knack, Stephen and Philip Keefer 1995. Institutions and Economic Performance: Cross-Country Tests Using Alternative Institutional Measures, Economics and Politics 7 (3): 207-27.

Knack, Stephen and Philip Keefer 1997. Why Don’t Poor Countries Catch Up? A Cross-National Test of an Institutional Explanation, Economic Inquiry 35 (3): 590602.

Lambsdorff, Johann Graf 2005. Consequences and Causes of Corruption: What do we Know from a Cross-Section of Countries? Universität Passau Wirtschaftwissenschaftliche Fakultät Diskussionsbeitrag Nr. V-34-05. University of Passau: Passau.

Lieven, Michael 1999. "Butchering the Brutes All Over the Place": Total War and Massacre in Zululand 1879, History 84 (276): 614-32.

Mamdani, Mahmood 1997. Citizen and Subject: Contemporary Africa and the Legacy of Late Colonialism. Oxford: James Currey.

Matthews, Robin C.O. 1986. The Economics of Institutions and the Sources of Growth, Economic Journal 96 (384): 903-18.

Mauro, Paolo 1995. Corruption and Growth, Quarterly Journal of Economics 110 (3): 681-712.

Meisel, Nicolas and Jacques Ould Aoudia 2008. Is "Good Governance" a Good Development Strategy? Working Paper No. 58. Agence Française de Développement (AFD): $\quad$ Paris. Available HTTP: <http://www.afd.fr/jahia/webdav/site/afd/users/admirecherche/public/DT/WP_58_GB _pour_mise_en_ligne.pdf $>$

Moses, A. Dirk 2000. An Antipodean Genocide? The Origins of the Genocidal Moment in the Colonization of Australia, Journal of Genocide Research 2 (1): 89106.

Murphy, Kevin M., Andrei Shleifer and Robert W. Vishny 1989. Industrialization and the Big Push, Journal of Political Economy 97 (5): 1003-26. 
North, Douglass C. 1984. Three Approaches to the Study of Institutions, in Collander, David C. (ed.) Neoclassical Political Economy: The Analysis of Rent-Seeking and DUP Activities, Cambridge Mass: Ballinger Publishing Co.

North, Douglass C. 1990. Institutions, Institutional Change and Economic Performance. Cambridge: Cambridge University Press.

North, Douglass C. 1995. The New Institutional Economics and Development, in Harriss, John, Janet Hunter and Colin Lewis (eds) The New Institutional Economics and Third World Development, London: Routledge.

Olson, Mancur 1997. The New Institutional Economics: The Collective Choice Approach to Economic Development in Clague, Christopher (ed.) Institutions and Economic Development, Baltimore: Johns Hopkins University Press.

Sale, Kirkpatrick 1990. The Conquest of Paradise: Christopher Columbus and the Columbine Legacy. New York: Alfred A. Knopf.

Snipp, C. Matthew 1989. American Indians: The First of the Land. New York: Russell Sage Foundation.

Stannard, David E. 1993. American Holocaust: The Conquest of the New World. New York: Oxford University Press USA.

Stiffarm, Lenore A. and Phil Lane Jr. 1992. The Demography of Native North America: A Question of American Indian Survival, in Jaimes, M. Annette (ed.) The State of Native America: Genocide, Colonization and Resistance, Boston: South End Press.

Stiglitz, Joseph E. 1987. Learning to Learn, Localized Learning and Technological Progress, in Dasgupta, Partha and Paul Stoneman (eds) Economic Policy and Technological Development, Cambridge: Cambridge University Press.

Stiglitz, Joseph E. 1989a. On the Economic Role of the State, in Heertje, Arnold (ed.) The Economic Role of the State, Amsterdam: Bank Insinger de Beaufort NV.

Stiglitz, Joseph E. 1989b. Markets, Market Failures and Development, American Economic Review 79 (2): 197-203.

Stiglitz, Joseph E. 2007. Making Globalization Work. London: Penguin.

Tatz, Colin 1999. Genocide in Australia, Journal of Genocide Research 1 (3): 315-52. 